\title{
Application of Solar Absorption Refrigeration in Milk Pasteurization
}

\author{
Sanjay Mitkari, B P Ronge
}

\begin{abstract}
Pasteurization coupled with refrigeration makes milk safe for human consumption and also extends the shelf-life of the milk. In a milk processing plant, hot water is used as heating medium and chilled water as cooling medium .In milk pasteurization heating and cooling process of milk was integrated by using plate heat exchangers known as regeneration section which saves $82.36 \%$ energy. Refrigeration plant for milk processing contributes approx. $30 \%$ of total electricity load. This electricity load can be reduced by using vapor absorption refrigeration system (VARS) which requires heat input in the form of hot water. In the present study the VARS uses 1, 1, 1 tetrafluroethane $(\mathrm{R} 134 a)$ as refrigerant and n,n-dimethyl formamide (DMF) as absorbent. The COP of the system was obtained between 0.48 to 0.71 and refrigeration capacity varied from $0.69 \mathrm{~kW}$ to $2 \mathrm{~kW}$. The absorption refrigeration system requires $1.4 \mathrm{~kW}$ of hot water per $\mathrm{kW}$ of refrigeration capacity. Thus the integration of solar energy with absorption refrigeration plays important role in energy optimization and sustainable development in milk processing industry.
\end{abstract}

Keywords: Pasteurization, Vapor absorption refrigeration system, Coefficient of performance, Dimethyl formamide, tetrafluroethane.

\section{I.INTRODUCTION}

Milk is an essential commodity but it is the most perishable and has only few hours of shelf life. To arrest bacterial growth and metabolism the temperature of the milk should be reduced to $2^{\circ} \mathrm{C}$ to $5^{\circ} \mathrm{C}$ within 4 hours hence, the time factor is the most important aspect in the milk processing. In dairy industry the first process integration was carried out due to plate heat exchangers for pasteurization process. In High Temperature-Short Time (HTST) pasteurization, heating and cooling of milk is carried out in plate heat exchanger (PHE). Due to PHE the regeneration section saves $82.36 \%$ energy in heating and cooling process of milk. Milk Cooling is done through a plate heat exchanger with cold water or brine being the cooling medium. This system has the advantages of being safe as the refrigerant is not directly used causing less damage in case of a leakage and the temperature can be easily controlled.

Revised Manuscript Received on December 30, 2019.

* Correspondence Author

*Sanjay Mitkari, Research scholar at SVERI,s college of engineering Pandharpur, Maharashtra, India. Email: sgmitkari.nbnscoe@gmail.com / sanjay.mitkari@raisoni.net

Dr B P Ronge, Research scholar at SVERI,s college of engineering Pandharpur, Maharashtra, India.

(c) The Authors. Published by Blue Eyes Intelligence Engineering and Sciences Publication (BEIESP). This is an open access article under the CC BY-NC-ND license (http://creativecommons.org/licenses/by-nc-nd/4.0/)
The efficiency of plate heat exchanger is $20 \%$ higher than shell and tube heat exchanger [1]. Plate heat exchanger (PHE) acts as regenerator during pasteurization process and reduces energy consumption in milk processing dairies. Before pasteurization the batch method is a widely used for fast cooling of milk. This ensures rapid milk cooling because in a very short time it can cool large amounts of milk and reduce the temperature of the milk below the critical value of $10{ }^{\circ} \mathrm{C}$. Refrigeration plant for milk processing contributes approx. $30 \%$ of total electricity load and the high price of electricity motivate to use absorption refrigeration in milk cooling.[2].After pasteurization milk is cooled by conventional vapor compression cycle which requires electrical energy. The increased energy cost and uncertainty in energy supply encouraged an investigation of heat operated refrigeration systems [3] .François Boudéhenna et al conducted experimental study on $5 \mathrm{KW}$ capacity absorption refrigeration systems and recommended use of plate heat exchangers to improve its performance [4,5]. To reduce this electrical load the VARS has been found to be useful as it uses hot water as heat input and chills the water/brine equal to or less than $0^{\circ} \mathrm{C}$. VARS is a binary fluid i.e. refrigerant and absorbent and the selection of such binary fluid is very critical step in the success of VARS. In the present study 1,1 , 1 tetrafluroethane (R134a) is used as refrigerant and n, n-dimethylformamide (DMF) is used as absorbent which has high absorption capacity towards R134a and has very low partial pressure in the solution. Nezu et al have studied R134a as a refrigerant with various organic solvents as absorbent and showed that the R134a- DMF system is more advantageous than any other R134a-absorbent binary fluid pair [6].Giovani A Longo et al proposed a correlation to determine convective heat transfer coefficient for plate heat exchanger [7] Francisco Taboas studied plate heat exchangers as a generator and proved that the overall heat transfer coefficient depends on temperature of hot water. He also advised the use of waste heat or solar energy for such systems [8].Handong Wanga studied Diffusion Absorption Refrigeration driven by low-grade thermal energy such as solar energy and waste heat sources which can reduce the electricity [9]. The VARS has very low COP and these systems occupy large space therefore the development of more compact system is necessary to promote vapor absorption systems. In the present study commercially available compact brazed plate heat exchangers (BPHE) are used as the main components such as evaporator, condenser, absorber and generator. The system efficiency was experimentally investigated for solar hot water temperature in the range of $75^{\circ} \mathrm{C}$ to $90^{\circ} \mathrm{C}$. The strong solution concentration ie rich in refrigerant was in the range of $51.56 \%$ to $73.77 \%$.Integration of this system with milk processing is an important step towards utilizing clean source of energy and reduces electricity consumption. 


\section{Application of Solar Absorption Refrigeration in Milk Pasteurization}

Very few researchers have studied integration of solar energy in vapor absorption refrigeration system and significance of this in milk processing therefore limited data is available. The objective of the work presented here is to contribute the development of solar operated VARS and integration of this technology in milk processing which will bring sustainable development.

\section{II.DATA ANALYSIS}

The refrigeration system performance can be evaluated by two important parameters such as coefficient of performance (COP) and circulation ratio ( $f$ ).

$$
C O P=\frac{Q_{e}}{Q_{g}}
$$

The size of the various components such as evaporator, generator, condenser and absorber is determined by the circulation ratio. The circulation ratio is the amount of rich solution handled by the pump per unit mass of the refrigerant gas separated in the gas separator. The weak solution mass flow rate is given by $(f-1)$ Where $m_{s s}, m_{w s}, m_{r}$ are mass flow rate of strong solution, weak solution and pure refrigerant .

$$
f=\frac{m_{s s}}{m_{r}} \text { And } \quad f-1=\frac{m_{w s}}{m_{r}}
$$

\section{A. Heat Transfer}

The convective heat transfer coefficient on water side for plate heat exchangers was determined by the correlation developed by Wilson plot technique and used by G A Longo \&A. Gasparella [13]

$$
h_{w}=0.276\left(\frac{k_{w}}{D_{h}}\right) \operatorname{Re}^{0.76} P_{r}^{0.333}
$$

$$
\operatorname{Re}=\frac{G D_{h}}{\mu} \quad \operatorname{Re}=\frac{G D_{h}}{\mu}
$$

The average overall heat transfer coefficient in evaporator, condenser, generator, and absorber was determined by log mean temperature difference equation. Where total heat transfer area $A=N_{C H} A_{P}$

$$
U=\frac{Q}{N_{C H} A_{P}(L M T D)}
$$

The convective heat transfer coefficient on refrigerant side

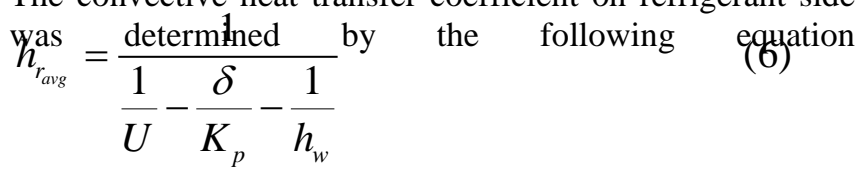

\section{III.HEAT TREATMENT OF MILK}

\section{A. Bulk Milk Cooler (BMC)}

Generally direct expansion method is used for building up the reserve of chilled water over a long period which can be replaced by absorption refrigeration system. The batch cooling allows heavy refrigerating loads to be carried with a system having a much smaller capacity. At night electricity rates are cheaper so you can build up your reserve of chilled water during night, thereby reducing running costs substantially.

Water-spray type bulk milk cooler has doube wall around the sides and bottom. Milk is stored in the horizntal cylindrical tank and water is sprayed from a perforate pipe over the surface of the tank as shown in fig1. The water sprayed on the outer surface forms a continuous film due to which heat transfer rate increases. The heat-exchange takes place from milk to the inner wall to the water film. The milk is agitated by mechanical agitator for better heat transfer. The outer wall (lining) is provided around the tank, especially on left and right sides to reduce convective heat losses.

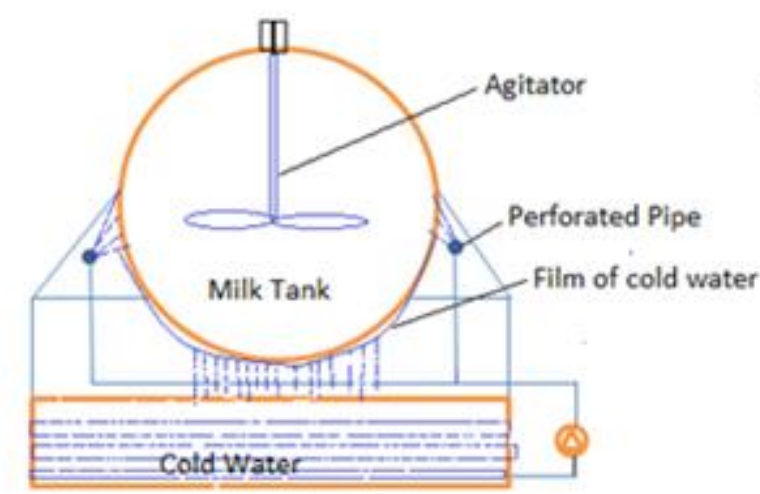

Figl: Water Spray Type Bulk Milk Cooler

\section{B. Milk Pasteurization:}

The direct expansion method is used to cool the brine equal to or less than $0^{\circ} \mathrm{C}$ temperature using plate heat exchanger and then stored in a tank. This brine solution is then circulated by a pump around the milk to be cooled. Due consideration is given for hygiene therefore hot water and cold water are used for heating and cooling of milk. The groups of plates are provided in between with connecting plates which make it possible to introduce or exit milk after each of the processes, like regeneration, heating and chilling. The gap between two plates is kept narrow as possible to increase heat transfer efficiency. But due to narrow gap the flow velocity and pressure drop will increase which makes adverse effect on performance of heat exchanger. The milk passage or gap between the plates is arranged into parallel flow channels as shown in fig 2.

Pasteurization involves heating milk between $72^{\circ} \mathrm{C}$ to $74^{\circ} \mathrm{C}$ for 15 to 20 seconds and then the milk is immediately cooled to $4^{\circ} \mathrm{C}$. One of the important parameter to judge the pasteurizer efficiency is the regeneration efficiency. 
In the regeneration section the cold milk from silo enters at $4{ }^{\circ} \mathrm{C}$ whereas hot milk after pasteurization enters at $72^{\circ} \mathrm{C}$ and heat exchange takes place as shown in fig 2 . This process integration of heating and cooling of milk will be most effective when the two liquids move in opposite direction, i.e. counter flow arrangement. Therefore in Regeneration section the temperature of cold unprocessed milk increases from $4^{\circ} \mathrm{C}$ to $60^{\circ} \mathrm{C}$ and which in turn cools the processed hot milk from $72^{\circ} \mathrm{C}$ to $10^{\circ} \mathrm{C}$. The detail of heat transfer during pasteurization is shown in table 2 .

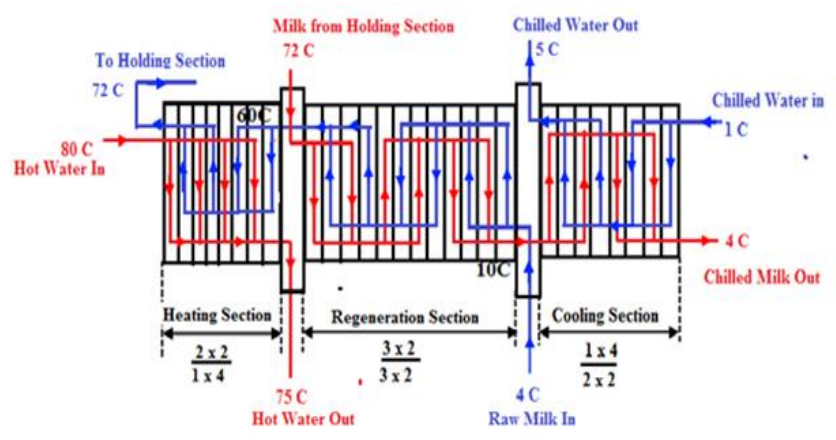

Fig2 : Plate heat Exchangers used in Heating and Cooling of milk

\begin{tabular}{|c|c|c|c|c|}
\hline \multicolumn{5}{|c|}{$\begin{array}{c}\text { Table 2: } \begin{array}{c}\text { Heat treatment of milk during } \\
\text { pasteurization }\end{array}\end{array}$} \\
\hline SN & Details & $\begin{array}{l}\text { Heating } \\
\text { section }\end{array}$ & $\begin{array}{l}\text { Regeneration } \\
\text { Section }\end{array}$ & $\begin{array}{l}\text { Cooling } \\
\text { Section }\end{array}$ \\
\hline 1 & LMTD : ${ }^{\circ} \mathrm{C}$ & 12.33 & 8.65 & 3.92 \\
\hline 2 & $\begin{array}{l}\text { Overall } \\
\text { Heat } \\
\text { Transfer } \\
\text { Coefficient } \\
(\mathrm{U}): \mathrm{W} / \mathrm{m}^{2 \circ} \mathrm{C}\end{array}$ & 675 & 1012 & 1233 \\
\hline 3 & $\begin{array}{l}\text { Number of } \\
\text { plates(N) }\end{array}$ & 13 & 48 & 17 \\
\hline 4 & $\begin{array}{l}\text { Mass Flow } \\
\text { rate } \\
(\mathrm{m}): \mathrm{LPH}\end{array}$ & $\begin{array}{l}\text { Hot } \\
\text { Water } \\
=1000\end{array}$ & Milk & $\begin{array}{l}\text { Chilled } \\
\text { Water }=1000\end{array}$ \\
\hline 5 & $\begin{array}{l}\text { Rate of Heat } \\
\text { Transfer } \\
\text { (Q):kW } \\
\end{array}$ & 7.33 & 32.21 & 5.8 \\
\hline 6 & $\begin{array}{l}\text { Total Area } \\
(\mathrm{A}): \mathrm{m}^{2}\end{array}$ & 0.88 & 3.68 & 1.2 \\
\hline
\end{tabular}

IV.EXPERIMENTAL SET UP

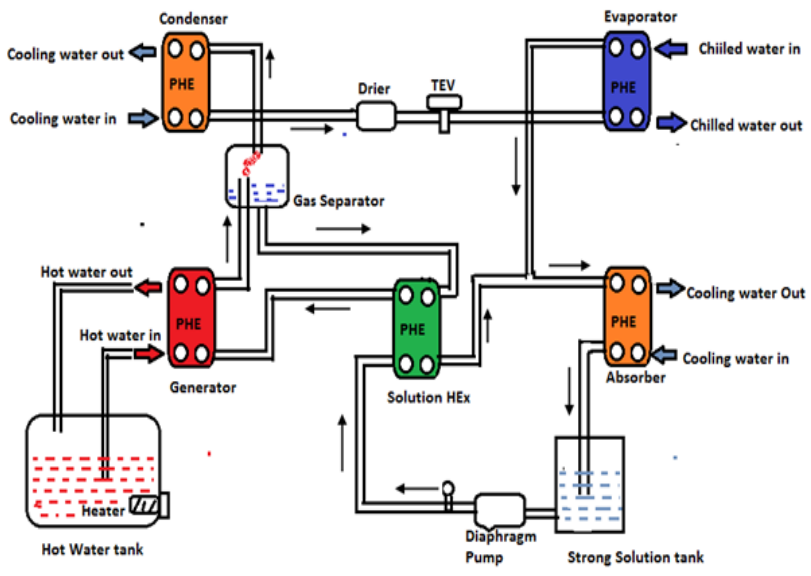

Fig3: Schematic diagram of Experimental set-up
Schematic diagram of an experimental setup is shown in fig 3.The setup consists of 18 numbers of thermocouples to record temperatures at the inlet and outlet of each component on refrigerant side and waterside with a measurement uncertainty up to $+/-0.5^{\circ} \mathrm{C}, 6$ numbers of pressure gauges with a measurement uncertainty up to $+/-1.2 \% .4$ number of flow meter on water side with measurement uncertainty of $+/-2.5 \%$ whereas 3 number of flow meter on refrigerant side with a measurement uncertainty of $+/-1 \%$.. Fig 4 shows the selection of PHE, Table1 gives the geometrical characteristics of the five BPHE, used as evaporator, condenser, absorber, generator and solution heat exchanger. It also consists of strong solution tanks, diaphragm type solution pump, hot water tank with PID controller, drier, gas separator, piping and valves.

Strong solution tank is of 4 liters capacity and was initially filled with 2 liters of absorbent solution. The refrigerant R134a was charged in the absorbent solution thus a strong solution was prepared. The strong solution was pumped to a pressure 8-10bar by using diaphragm type solution pump through the solution heat exchanger to the generator. The solar water heater with an electric water heater of capacity $4 \mathrm{~kW}$ as a backup provides hot water and a PID temperature controller was used to ensure inlet temperature of hot water to the generator. Due to heat input to the generator the refrigerant gas was boiled off in the generator and then separated in the gas separator and passes to the condenser. In the condenser cooling water was allowed to circulate at constant flow rate of $400 \mathrm{LPH}$ at $25^{\circ} \mathrm{C}$ which absorbs the heat of condensation. The refrigerant gas thus condensed in the condenser was then allowed to pass through expansion valve to reduce its pressure and the temperature. The low pressure and low temperature refrigerant passing through evaporator, absorbs heat from the chilled water and evaporates. Therefore the temperature of chilled water decreases, known as refrigeration effect or capacity refrigeration. The refrigerant gas from evaporator and the weak solution remained at the bottom of the gas separator were mixed just before the absorber. The heat of absorption was removed by the cooling water circulated in the absorber to keep low temperature in the absorber.

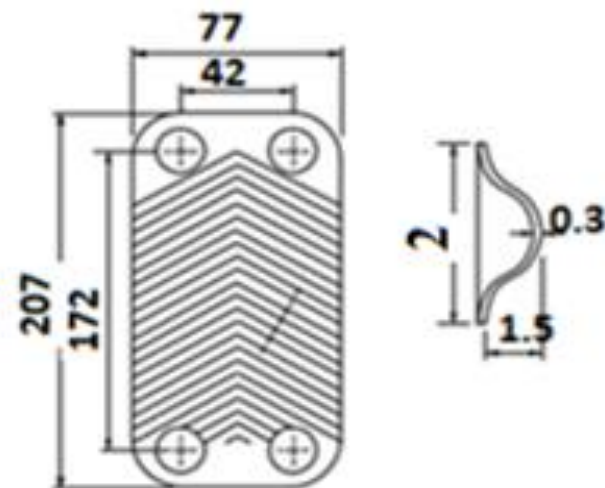

All dimensions in $\mathrm{mm}$

Fig 4: Selection of Plate Heat Exchanger 


\section{Application of Solar Absorption Refrigeration in Milk Pasteurization}

\section{A. Design of solar Flat plate solar collector}

The Solar water heating system used here is an evacuated tube collector with heat pipe module each of area $3.25 \mathrm{~m} 2$ to get hot water to the Vapor Absorption Machine (VAM). The overall performance of solar concentrator is given by following equation.

$\eta_{t h}=\eta_{\text {opt }}-\frac{U_{L}\left(T_{a b}-T_{a t m}\right)}{I}$

The overall performance of the concentrator depends on optical efficiency which is directly related to the reflector performance i.e. its specular reflectivity $(>0.95)$. A typical reflector consists of substrate material and coating material. Generally glass, metal, plastics, or polymers are used as substrate material whereas highly reflective materials such as silver or aluminum are used as coating material. Energy absorbed by the collector plate is given by

$\mathrm{Q}=\mathrm{K} \times \mathrm{S} \times \mathrm{A}$,

Where efficiency of collector plate $(K=0.70)$, average solar radiation $\left(S=516 \mathrm{w} / \mathrm{m}^{2}\right)$, Area of collector plates (A).Hence approximate area of the collector plates required if heat input to the generator of VARS is $2.8 \mathrm{~kW}$.

$A=2817 /(516 \times 0.7)$

$\mathrm{A}=7.8 \mathrm{~m}^{2}$.

\section{V.RESULT AND DISCUSSION:}

\section{A. Bulk Milk Cooling}

The bulk milk cooler of 2000 liters capacity, water jacket with refrigeration cooling system is used which reduces temperature of milk about 4 to $10^{\circ} \mathrm{C}$ within 2 to 3 hours. This method accelerates the heat transfer rate therefore cooling time of milk reduced by $50 \%$ compared to a conventional direct expansion method. Such bulk milk cooler also helps to maintain milk quality for long time up to 8 to 12 hours during load shedding when power supply is off.

\section{B. Integration of cooling and heating of milk during pasteurization}

In this study milk processing capacity of 500 LPH was considered, the heat transfer parameters given in tale (1). The PHE consists of three sections regeneration, cooling and heating sections. The raw unprocessed milk available at $4^{\circ} \mathrm{C}$ was heated to a temperature of $72^{\circ} \mathrm{C}$ for 15 seconds and the processed hot milk is cooled to $4^{\circ} \mathrm{C}$. The overall heat transfer coefficient during this heating and cooling of milk in different sections was calculated. The thickness of plate is about 0.5 to $1.25 \mathrm{~mm}$ and the area of single plate is $0.08 \mathrm{~m}^{2}$. The gap between plates is about 3 to $6 \mathrm{~mm}$ wide.

Regeneration efficiency $=\frac{\text { Steam Load }}{\text { Total Heating Load }}$

$=\frac{72-60}{72-4} \times 100$

\section{Re generation efficiency $=82.36 \%$}

Thus, PHE in regeneration section saves about $82.36 \%$ of heating and cooling energy Therefore heat load in the heating section is $17.64 \%$ of the total heating load. The fluid milk plant requires approx. $0.25 \mathrm{~kg}$ of steam per liter of milk.

\section{Table 1: Geometrical characteristics of BPHE}

$\begin{array}{lc}\text { Type: Brazed plate heat exchanger } & \\ \text { Plate Length, m: } & 0.054 \\ \text { Plate Width, m: } & 0.072 \\ \text { Plate Height, } \mathrm{m} \text { : } & 0.206 \\ \text { Number of plates N: } & 14-18 \\ \text { Area of the single plate, } \mathrm{A}(\mathrm{m} 2): & 0.016 \\ \text { Plate thermal conductivity }(\mathrm{W} / \mathrm{m} \mathrm{K}): & 15.6 \\ \text { Hydraulic diameter: } & 4 \mathrm{~mm} \\ \text { Plate thickness: } & 0.3 \mathrm{~mm} \\ \text { Corrugation type: } & \text { chevron } \\ \text { Angle of corrugation: } \phi \text { (degrees) }= & 60 \\ \text { Corrugation amplitude, } \mathrm{b} \text { (mm) } & 2.0\end{array}$

\section{Integration of Solar water heating system with absorption refrigeration system}

The hot water generated by the solar system was used for heating of milk during pasteurization and the same hot water was utilized in absorption refrigeration machine to produce cooling. Thus the heating and cooling demand in a dairy milk processing can be fulfilled by integrating solar system with absorption refrigeration system. This will optimize the energy consumption in milk processing and bring sustainable development in dairy industry. Table 3 shows the thermal efficiency of the solar water heating system. During daytime the amount solar radiation reaching on the earth surface varies. The incident solar radiation increases from 430 to 855 $\mathrm{W} / \mathrm{m} 2$ and the temperature of hot water increases from $88^{\circ} \mathrm{C}$ to $94.03^{\circ} \mathrm{C}$

\begin{tabular}{|c|c|c|c|c|}
\hline \multicolumn{5}{|c|}{$\begin{array}{c}\text { Table 3: Performance results of solar thermal } \\
\text { collector (area: } 9.75 \mathrm{~m}^{2} \text { ) }\end{array}$} \\
\hline Sr No & $\begin{array}{l}\text { Solar } \\
\text { radiation } / \mathbf{m}^{2}\end{array}$ & $\begin{array}{l}\text { In } \\
\left({ }^{\circ} \mathrm{C}\right)\end{array}$ & $\begin{array}{l}\text { Out } \\
\left({ }^{\circ} \mathrm{C}\right)\end{array}$ & $\begin{array}{l}\text { Thermal } \\
\text { efficiency }\end{array}$ \\
\hline 1 & 430.42 & 83.61 & 88.13 & 0.35 \\
\hline 2 & 561.84 & 74.37 & 80.32 & 0.38 \\
\hline 3 & 652.31 & 86.01 & 92.50 & 0.42 \\
\hline 4 & 770.12 & 87.16 & 95.42 & 0.45 \\
\hline 5 & 855.31 & 84.32 & 94.03 & 0.47 \\
\hline
\end{tabular}

Table4 shows the performance of VARS at different hot water inlet temperature at the generator. The performance evaluation of the VAM was carried out with hot water inlet temperature varying between $75^{\circ} \mathrm{C}$ and $90^{\circ} \mathrm{C}$ and the coefficient of performance (COP) was found to be in the range of 0.48 to 0.71 . The system was designed for constant flow rate of hot water, chilled water and cooling water as 480LPH, 200LPH and $400 \mathrm{LPH}$ respectively. The cooling water used in parallel in the condenser and absorber is available at 25C.The heat rejected in the condenser and absorber increases the cooling water temperature from $25^{\circ} \mathrm{C}$ to $30^{\circ} \mathrm{C}$. The temp of chilled water decrease from $25^{\circ} \mathrm{C}$ to $18^{\circ} \mathrm{C}$ as hot water temp increase from $75 \mathrm{C}^{\circ}$ to $90^{\circ} \mathrm{C}$.

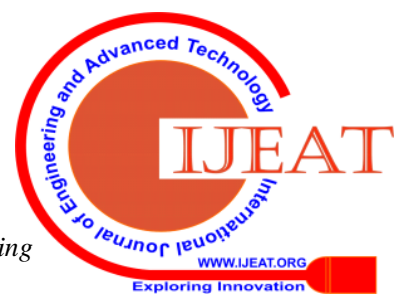


The system COP increase from 0.48 to 0.71 because refrigeration capacity increases from $0.69 \mathrm{~kW}$ to $2 \mathrm{~kW}$.

\begin{tabular}{|c|c|c|c|c|c|c|}
\hline \multicolumn{7}{|c|}{$\begin{array}{c}\text { Table 4: COP of VARS at different hot water } \\
\text { temperatures inlet to the generator }\end{array}$} \\
\hline \multicolumn{2}{|c|}{ Hot water } & \multicolumn{2}{|c|}{ Cooling water } & \multicolumn{2}{|c|}{ Chilled water } & \multirow{2}{*}{$\begin{array}{l}\text { C } \\
\text { o }\end{array}$} \\
\hline \multicolumn{2}{|c|}{ Flow rate $=480 \mathrm{LPH}$} & \multicolumn{2}{|c|}{ Flow rate $=400 \mathrm{LPH}$} & \multicolumn{2}{|c|}{ Flow rate $=200 \mathrm{LPH}$} & \\
\hline $\begin{array}{l}\text { Inlet } \\
\text { Temp } \\
\text { in }{ }^{\circ} \mathrm{C}\end{array}$ & $\begin{array}{l}\text { Outlet } \\
\text { Temp in } \\
{ }^{\circ} \mathrm{C}\end{array}$ & $\begin{array}{l}\text { Inlet } \\
\text { Temp in } \\
{ }^{\circ} \mathrm{C}\end{array}$ & $\begin{array}{l}\text { Outlet } \\
\text { Temp in } \\
{ }^{\circ} \mathrm{C}\end{array}$ & $\begin{array}{l}\text { Inlet } \\
\text { Temp in } \\
{ }^{\circ} \mathrm{C}\end{array}$ & $\begin{array}{l}\text { Outlet } \\
\text { Temp in } \\
{ }^{\circ} \mathrm{C}\end{array}$ & $\mathbf{P}$ \\
\hline 75 & 72.58 & \multirow{4}{*}{25.83} & 28.08 & \multirow{4}{*}{25.83} & 22.89 & 0.48 \\
\hline 80 & 76.6 & & 29.69 & & 20.68 & 0.63 \\
\hline 85 & 81.29 & & 30.11 & & 20.04 & 0.67 \\
\hline 90 & 85.98 & & 30.95 & & 18.8 & 0.71 \\
\hline
\end{tabular}

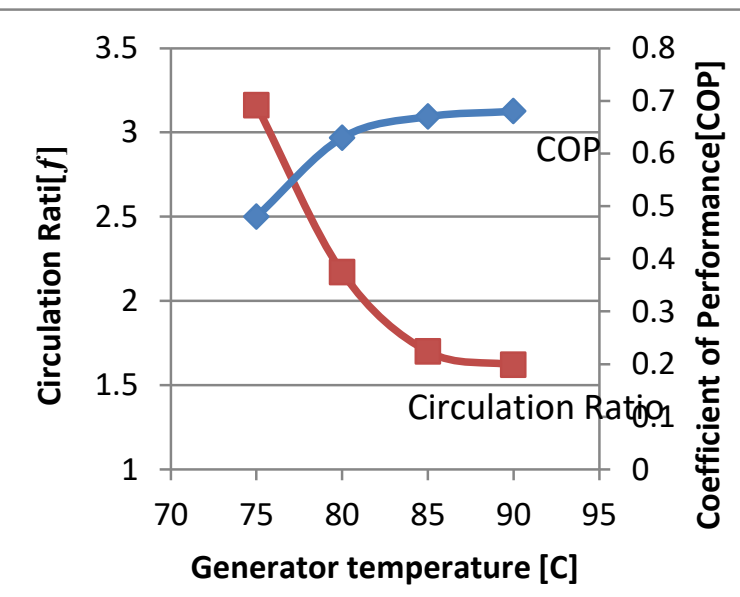

Fig 5: Effect of Generator temperature on COP of the VARS

Fig 5 shows that with increase in generator temperature the circulation ratio decrease. Therefore the amount of strong solution per unit mass of refrigerant vapors separated in the generator cum separator decrease. This leads to decrease in heat input supplied in the generator and also increases the refrigerating effect in the evaporator which increases the COP of the system.

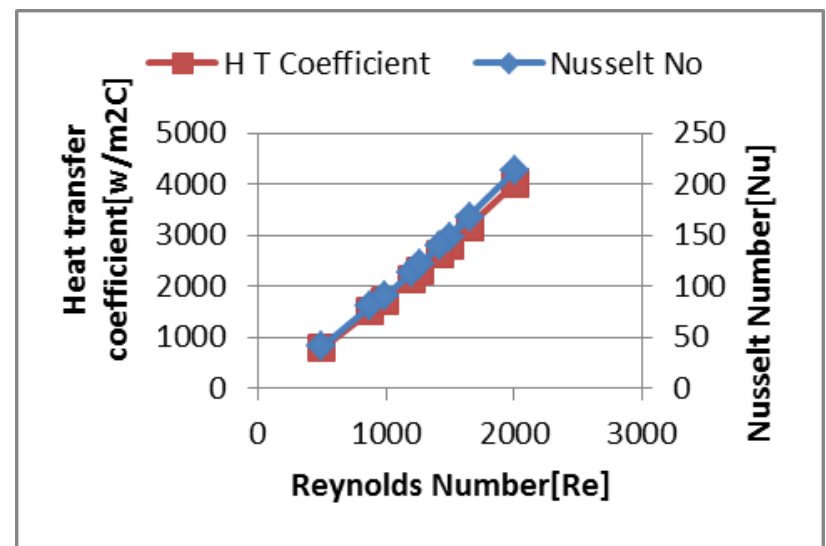

Fig 6: Effect of Reynolds number on absorber heat transfer coefficient during mixing.

Fig 6 shows the effect of Reynolds number on heat transfer coefficient. Heat transfer coefficient and Nusselt number are the two important parameters in heat transfer investigations. Increase in absorber efficiency increases the rate of refrigerant gas absorbed in the absorber which increases the solution Reynolds number. Thus the increase in Reynolds number increases the Nusselt number and Sherwood number which in turn increase heat transfer coefficient.

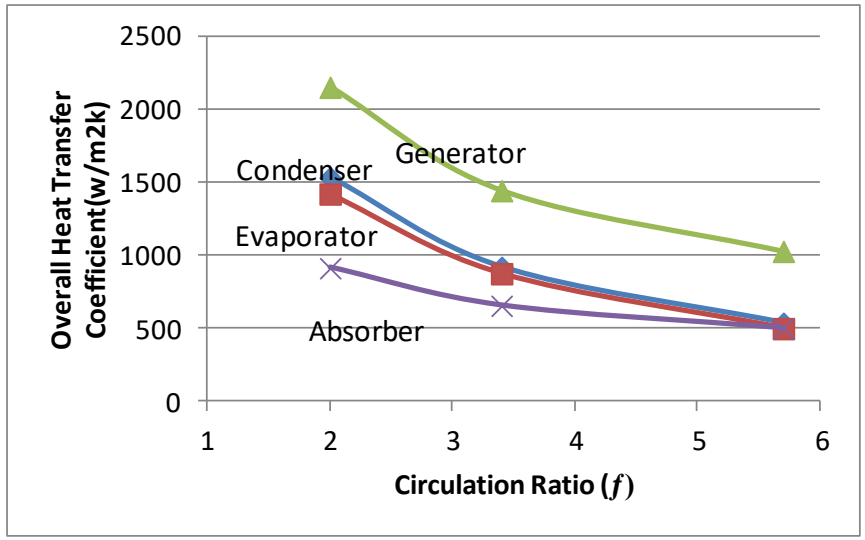

Fig 7: Effect of Overall heat transfer coefficient on Circulation ratio

Fig 7 shows the effect of overall heat transfer coefficient (U) on circulation ratio. The performance of system depends on the performance of an individual component such as evaporator, generator absorber and condenser. It is observed that as hot water temperature in the generator increases the Reynolds number of the refrigerant solution increase. With increase in Reynolds number the convective heat transfer coefficient and thus the overall heat transfer in each component increases. As the overall heat transfer coefficient in evaporator, condenser, absorber and generator increases the circulation ratio decrease which causes increase in COP of the system.

\section{VI.CONCLUSION}

The bulk milk cooler reduces cooling time of milk by 50 $\%$ compared to a conventional method and also reduces the risk of milk temperature increase during load shedding when power supply is off.

$>$ Due to plate heat exchangers heating and cooling process were integrated thus it saves $82.36 \%$ energy during milk pasteurization.

$>$ The solar evacuated tube collector with heat pipe provides hot water temperature of up to $90^{\circ} \mathrm{C}$ with average radiation of $800 \mathrm{~W} / \mathrm{m}^{2}$. As hot water temp increase from $75 \mathrm{C}^{\circ}$ to $90^{\circ} \mathrm{C}$ the COP increase from 0.48 to 0.71 . Vapor Absorption Refrigeration System requires $1.4 \mathrm{~kW}$ of hot water input per $\mathrm{kW}$ of refrigeration capacity.

$>$ Thus the integration of solar hot water system with absorption refrigeration machine optimizes energy consumption in dairy milk processing.

Published By:

Blue Eyes Intelligence Engineering 


\section{Application of Solar Absorption Refrigeration in Milk Pasteurization}

\begin{tabular}{|l|}
\hline Nomenclature \\
A $=$ Total Heat transfer area \\
$\mathrm{b}=$ height of corrugation $C_{P}=$ Specific heat \\
$\mathrm{Dh}=$ Hydraulic diameter $=2 \mathrm{~b}$ \\
$f=$ Circulation Ratio \\
$\mathrm{G}=$ mass flux \\
$\mathrm{I}=\mathrm{Beam}$ radiation $\left(\mathrm{W} / \mathrm{m}^{2}\right)$ \\
$\mathrm{m}=$ mass flow rate \\
$\mathrm{Nch}=$ Number of channels in $\mathrm{PHE}$ \\
$\mathrm{Nu}=$ Nusselt Number \\
$\mathrm{N}=$ No of effective plates \\
$\mathrm{Pr}=$ Pandle Number \\
$\mathrm{Re}=$ Reynolds Number \\
$T_{a b}$ Average absorber temperature $\left({ }^{\circ} \mathrm{C}\right)$ \\
$T_{a t m}=$ Ambient temperature $\left({ }^{\circ} \mathrm{C}\right)$ \\
$U_{L}=$ Overall heat loss coefficient $\left(\mathrm{W} / \mathrm{m}^{2}-\mathrm{k}\right)$ \\
$\mathrm{W}=$ width of the plate \\
$\eta_{t h}=$ Overall thermal efficiency \\
$\eta_{\text {opt }}=$ Optical efficiency \\
$\delta=$ Plate thickness \\
$\mu=$ dynamic viscosity \\
\end{tabular}

\section{REFERENCES}

1. Huminic, G. and Huminic, A. Application of nanofluids in heat exchangers: A reviews (2012) Renewable Sustainable Energy Rev., 16: 5625-5638.

2. Z. Taghizadeh Tabari \& S. Zeinali Heris (2015) Heat Transfer Performance of Milk Pasteurization Plate Heat Exchangers Using MWCNT/Water Nanofluid, Journal of Dispersion Science and Technology, 36:2, 196-204, DOI:10.1080/01932691.2014.894917

3. S.N. Sapali , S.M.Pise , A.T.Pise , D.V.Ghewade," Investigations of waste heat recovery from bulk milk cooler" Case Studies in Thermal Engineering4(2014)136-143 http://dx.doi.org/10.1016/j.csite.2014.09.003

4. François Boudéhenna, Sylvain Bonnota , Hélène Demaslesa, Florent Lefrançoisa, Maxime Perier-Muzeta, DelphineTriché, "Development and performances overview of ammonia-water absorption chillers with cooling capacities from 5 to $100 \mathrm{~kW}$,, Energy Procedia 91 ( 2016 ) 707 716

5. G.A. Florides a, S.A. Kalogirou a, S.A. Tassou b, L.C. Wrobel, "Design and construction of a $\mathrm{LiBr}-$ water absorption machine, Energy Conversion and Management" 44 (2003) 2483-2508

6. Y. Nezu, N. Hisada, T. Ishiyama, K. Watanabe, Thermodynamic properties of working-fluid pairs with R-134a for absorption refrigeration system, in:Natural Working-Fluids, IIR Gustav Lorentzen Conf. 5th, China, Sept. 17-,2002, pp. 446-453

7. Giovanni A. Longo, Simone Mancin, and Giulia Righetti, and Claudio Zilio, HFC404A condensation inside a small brazed plate heat exchanger: comparison with the low GWP substitutes propane and propylene, International Journal of Refrigeration (2017), http://dx.doi.org/doi: 10.1016/j.ijrefrig.2017.05.017

8. Francisco Ta'boas a, Manel Valle`s b, Mahmoud Bourouis b, Alberto Coronas, Flow boiling heat transfer of ammonia/water mixture in a plate heat exchanger, in t e r $\mathrm{n}$ a t i onal j o u rna $\mathrm{l}$ o f r e f r i g e ra t i o n $33(2010) 695-705$

9. Handong Wanga, A new style solar-driven diffusion absorption refrigerator and its operating characteristics, Energy Procedia 18 (2012) $681-692$

\section{AUTHORS PROFILE}

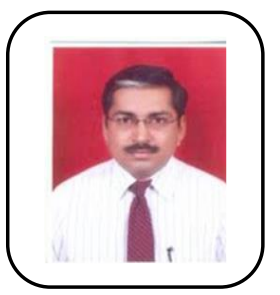

Mr Sanjay Mitkari, research scholar at SVERI,s college of engineering Pandharpur under Punyashlok Ahilyadevi Holkar Solapur University, Maharashtra, India..Also working as assistant professor at $\mathrm{G} H$ Raisoni college of Engineering and Management Pune. His research interests include, Heat transfer and fluid flow, Refrigeration. 